\title{
Academic Performance and the Role of Self-directed Learning, Self-esteem, and Grit among Nursing Students
}

\author{
Ryan Michael F. Oducado ${ }^{1}$ \\ ${ }^{1}$ West Visayas State University, Philippines \\ Coresponding author: rmoducado@wvsu.edu.ph
}

\begin{abstract}
Background: understanding the factors affecting academic performance is important to support and promote the academic success of students. While there have been several studies on nursing students' academic performance, the role of self-directed learning readiness, self-esteem, and grit among Filipino nursing students have not been well documented.

Purpose: this study aimed to determine the relationship of self-directed learning readiness, self-esteem, and grit to the perceived academic performance of nursing students.

Methods: this correlational research was conducted among undergraduate sophomore nursing students in a higher education institution in the Philippines using adopted research instruments. Spearman's rho tested the correlation between variables.

Results: the results indicated that self-directed learning readiness $\left(r_{s}=.360, p=.000\right)$, self-esteem $\left(r_{s}=.301, p=.000\right)$, and grit $\left(r_{s}=.186, p=.023\right)$ were significantly related to the academic performance of sophomore nursing students.

Conclusion: psychological resources such as self-directed learning readiness, selfesteem, and grit contribute to students' academic performance. Strategies that encourage self-directed learning, increase self-esteem, and cultivate grit are needed to support students' academic success in nursing school.
\end{abstract}

Keywords:

Academic Performance; grit; self-directed learning; self-esteemt nursing students. 


\section{BACKGROUND}

Students' academic performance is an important indicator of quality education. Assessing students' academic performance and associated factors are necessary to suitably identify factors that promote students' success in the nursing program. This is particularly important in nursing education given that nursing is a highly demanding course. Guidance in their academics is an expressed need of nursing students (Oducado et al., 2017). Research regarding academic performance is essential since it contributes to students' terminal competencies and clinical performance in nursing school (BeloDelariarte et al., 2018; Oducado et al., 2019). Also, prior researches have established a significant correlation between academic performance and the licensure examination for nurses (Kiblasan \& Ligligen, 2020; Oducado et al., 2019a; Soriano, 2016). Good academic performance of students in nursing school increases their chance of passing the board examination for nurses (Kiblasan \& Ligligen, 2020) which is a basic requirement to practice the profession in the country (Oducado \& Penuela, 2014). At present, there has been a growing interest in nursing students' academic failure because of its negative impact on the availability of future nurses (Dube \& Mlotshwa, 2018). Identification of factors affecting academic performance may help in promoting students' retention in the program, thus may play a part in alleviating the shortages of nursing staff both locally and internationally (Mthimunye \& Daniels, 2019).

Meanwhile, studies have shown that academic or intellectual and non-academic factors influence students' academic performance (Oducado \& Penuela, 2014). These variables should be investigated as foundations of the nursing programs (Oducado et al., 2020). A systematic review by Mthimunye \& Daniels (2019) identified many significant predictors of nursing students' academic performance to include but not limited to demographic factors, preadmission qualifications, emotional intelligence, self-control, and resilience. The study of Dube \& Mlotshwa (2018) among nursing students in South Africa identified parental involvement in education, good relationships between teachers and students, technological gadgets, internet connection, and adequate learning facilities as contributing factors to better academic performance.

Another study in South Africa by Arendse (2020) looked into the psychosocial factors predicting the academic performance of first-year college nursing students. The study of Khaliq et al. (2019) among nursing students in Pakistan revealed that teaching method, time management, attendance of students, and sleep have a positive influence on the academic performance of nursing students. According to Khatun et al. (2020), age, gender, education level of parents, monthly family income, study and sleeping hours per day, and grade point average were significantly related to the academic performance of nursing students in Bangladesh.

The works of Fajar et al. (2019) among nursing students in Pakistan, Alshammaria et al. (2018) among nursing students in the Kingdom of Saudi Arabia, Alos et al., (2015) among nursing students in the Philippines assessed teacher, student, home, and schoolrelated factors that affect the academic performance of nursing students. Type of high school attended, senior high school strand, English language proficiency, stress, and academic factors were also demonstrated to be associated with the academic performance of Filipino nursing students (Oducado \& Penuela, 2014; Oducado et al., 2020; Malaga \& Oducado, 2021; Oducado \& Estoque, 2021). 
Understanding the factors affecting academic performance is important to support and promote the academic success of students. However, little has been written on psychosocial factors that influence academic success among nursing students (Beauvais et al., 2014; Oducado et al., 2019a). Moreover, while there have been several studies on nursing students' academic performance, the role of self-directed learning readiness, self-esteem, and grit among Filipino nursing students have not been well documented.

\section{OBJECTIVE}

This study aimed to determine the correlation of self-directed learning readiness, selfesteem, and grit to the perceived academic performance of nursing students.

\section{METHODS}

This was a correlational study. A total of 149 conveniently chosen second-year nursing students in a higher education institution in the Philippines participated in the study. Data were collected in September 2020. Students' academic performance was determined following the approach cited in prior studies (Terry \& Peck, 2020; Oducado $\&$ Estoque, 2021). Participants were asked about their self-rated academic performance as compared to other students with responses ranging from " 1 - very poor" to " 5 - very good". Three measures were also adopted in the study. The self-directed learning readiness scale (SDLRS) for nursing education by Fisher et al. (2001) consisted of 40 items with three subscales namely: self-management, desire for learning, and selfcontrol. The participants answered on a 5-point Likert scale ("1-strongly disagree" to "5-strongly agree") the extent to which the item was descriptive of their own characteristics. The total item pool of the SDLRS had a reported reliability coefficient of $\alpha=.92$ (Fisher et al., 2001). The self-esteem scale (SES) by Rosenberg (1965) is a 10 -item self-report measure of global self-esteem. The participants were asked to answer on a 4-point scale ranging from "1-strongly disagree" to "4-strongly agree". A study among Filipino youth demonstrated a reliability coefficient of $\alpha=.77$ (Reyes et al., 2017). The short grit scale (GRIT-S) by Duckworth \& Quinn (2009) had eight items with 2-factors: consistency of interest and perseverance of effort. The participants responded on a 5-point Likert scale ranging from "1-not at all like me" to "5-very much like me". The GRIT-S displayed a reliability coefficient of $\alpha=.73$ to .83 (Duckworth \& Quinn, 2009). For this study, the adopted scales had the following overall reliability estimates, SDLRS $\alpha=.95$, SES $\alpha=.83$ and GRIT-S $\alpha=.74$. Data were coded and entered into the SPSS program (version 23). The analyses were done through the use of univariate statistics (frequency, percentage mean, \& standard deviation), and bivariate statistics (Spearman rho correlation). Alpha level of significance was set at .05.

\section{RESULTS}

Table 1 shows that sophomore nursing students were 19 to 20 years old. The majority were females $(70.5 \%)$ and had a monthly family income of less than 49,999 pesos and below $(64.4 \%)$. 
Table 1. Participants' demographics

\begin{tabular}{|c|c|c|}
\hline Categories & $f$ & $\%$ \\
\hline \multicolumn{3}{|l|}{ Age } \\
\hline 20 years old & 76 & 51.0 \\
\hline 19 years old & 73 & 49.0 \\
\hline \multicolumn{3}{|l|}{ Sex } \\
\hline Male & 44 & 29.5 \\
\hline Female & 105 & 70.5 \\
\hline \multicolumn{3}{|l|}{ Monthly Family Income } \\
\hline PHP 100,000 and above & 16 & 10.7 \\
\hline PHP 50,000 to 99,999 & 37 & 24.8 \\
\hline PHP 49,999 and below & 96 & 64.4 \\
\hline
\end{tabular}

Table 2 shows that the composite score in the self-directed learning readiness, selfesteem, and grit scales were 158.75 ( $\mathrm{SD}=18.35), 26.31 \quad(\mathrm{SD}=5.14)$, and 25.40 $(\mathrm{SD}=4.71)$, respectively. More than half $(52.3 \%)$ had an acceptable self-reported academic performance.

Table 2. Descriptive of major variables

\begin{tabular}{lcccc}
\hline \multicolumn{1}{c}{ Variables } & $M$ & $S D$ & $f$ & $\%$ \\
\hline Self-directed learning readiness & & & & \\
Self-esteem & 158.75 & 18.35 & & \\
Grit & 26.31 & 5.14 & & \\
Academic performance & 25.40 & 4.71 & & \\
$\quad$ Good/very good & 3.34 & .71 & & \\
Acceptable & & & 58 & 38.9 \\
$\quad$ Very poor/poor & & & 78 & 52.3 \\
& & & 13 & 8.8 \\
\hline
\end{tabular}

Table 3 shows that self-directed learning readiness $\left(r_{s}=.360, p=.000\right)$, self-esteem $\left(r_{s}=.301, p=.000\right)$, and grit $\left(r_{s}=.186, p=.023\right)$ were significantly correlated with the academic performance of nursing students.

Table 3. Correlation of independent variables to academic performance

\begin{tabular}{lcc}
\hline \multicolumn{1}{c}{ Independent Variables } & $r_{s}$ & $p$ \\
\hline Self-directed learning readiness & & .000 \\
Self-esteem & .360 & .000 \\
Grit & .301 & .023 \\
\hline
\end{tabular}




\section{DISCUSSION}

This study examined the relationship between self-directed learning readiness, selfesteem, grit, and academic performance of second-year nursing students. This study found that self-directed learning readiness was positively considerably correlated with students' academic performance. The study of Carson (2012) also found a correlation between self-directed learning and academic achievement among grades 8 through 12, taking online courses through a statewide online program in the Southeastern United States. Self-directed learning was likewise found to predict academic achievement among students in a Romanian University (Cazan \& Schiopca 2014). Similarly, selfdirected learning was the strongest predictor of academic achievement among freshmen students who were taking online English as a Foreign Language course in a public university (Torun, 2020). The result of this study suggests that more self-directed nursing students, with better self-management, self-control, and desire for learning, have higher academic performance. On the contrary, no significant association was reported between self-directed learning readiness and academic achievement of studentteachers in Pakistan (Hussain et al., 2019) and academic performance of first-year pharmacy students in the United States (Deyo et al., 2011) and students in health professional programs in Australia (Slater, 2018).

It was also demonstrated in this study that self-esteem was significantly correlated with academic performance. Similarly, the study of Aryana (2010) disclosed a significant positive association between self-esteem and academic achievement among preuniversity students in Iran. It was also found that there was a significant relationship between self-esteem and academic performance among university students in Pakistan (Arshad et al., 2015). Malaysian students with higher self-esteem were likewise found to perform better in their academics (Rosli et al., 2012). The same result was noted among nursing students in Iran (Kamali et al., 2009; Moradi et al., 2018). Those who feel more confident in themselves tend to have a higher academic achievement or vice versa. Self-esteem is one of the variables affecting students' academic achievement and special attention should be given on strengthening students' self-esteem (Sayehmiri et al., 2019).

Finally, this study found that grit was significantly related to academic performance. Similarly, grit was found to be a predictor of academic performance among nursing students in an Australian university (Terry \& Peck, 2020). Grit also predicted academic performance and persistence when considered in conjunction with academic variables among junior baccalaureate nursing students at one central New York college (Smith, 2017). Grit likewise predicted academic performance among a sample of first-year South African university students (Mason, 2018). Correspondingly, a systematic review indicated that overall grit level was positively associated with academic achievement (Lam \& Zhou, 2019). On the other hand, some scholars noted that grit was not a significant predictor of students' academic achievement or course success (Bazelais et al., 2016; Palisoc et al., 2017; Murphy, 2020). Nonetheless, grit may be an important personal resource contributing to nursing students' academic performance.

The findings of the study highlight that self-directed learning, self-esteem, and grit are positively linked to nursing students' academic performance. The results of this study suggest that nursing schools should develop interventions and approaches that support 
self-directed learning, promote healthy self-esteem, and nurture grit to assist and promote students' academic success.

The current study bears limitations. First, the sample for the study comprised only of sophomore nursing students in one nursing school. The findings cannot be generalized to all nursing students in the country and internationally. Secondly, the study relied only on students' self-report that is subject to bias. Also, the cross-sectional design of the study cannot infer causality between variables. Notwithstanding these limitations, this study contributes to the existing literature in this area. However, further research is required to confirm the findings of the current study.

\section{CONCLUSION}

Self-directed learning, self-esteem, and grit are valuable factors for students' academic success in nursing schools. The higher the self-esteem and the more self-directed and gritty the students are, the higher is their academic performance. The significant relationship between self-directed learning, grit, and academic performance in this study suggests that these variables may play vital roles in the persistence of nursing students on the challenges they encounter in nursing education. These variables may be important psychological constructs and personal resources that are instrumental for students' academic success in nursing school. Strategies that encourage self-directed learning, increase self-esteem, and cultivate grit are needed to support students' academic success.

\section{REFERENCES}

Alshammari, F., Saguban, R., Pasay-an, E., Altheban, A., \& Al-Shammari, L. (2017). Factors affecting the academic performance of student nurses: A cross-sectional study. Journal of Nursing Education and Practice, 8(1), 60-68. https://doi.org/10.5430/jnep.v8n1p60

Alos, S. B., Caranto, L. C., \& David, J. J. T. (2015). Factors affecting the academic performance of the student nurses of BSU. International Journal of Nursing Science, 5(2), 60-65. https://doi.org/10.5923/j.nursing.20150502.04

Arendse, J. P. (2020). Psychosocial factors predicting academic performance of firstyear college nursing students in the Western Cape, South Africa (Master's thesis). University of the Western Cape. http://hdl.handle.net/11394/8004

Aryana, M. (2010). Relationship between self-esteem and academic achievement amongst pre-university students. Journal of Applied Sciences, 10(20), 24742477. https://doi.org/10.3923/jas.2010.2474.2477

Belo-Delariarte, R. G., Oducado, R. M. F., \& Penuela, A. C. (2018). Terminal assessment of core nursing knowledge in a state university. Asia Pacific Journal of Multidisciplinary Research, 6(2), 10-17. http://hdl.handle.net/10419/210486

Beauvais, A. M., Stewart, J. G., DeNisco, S., \& Beauvais, J. E. (2014). Factors related to academic success among nursing students: A descriptive correlational 
research study. Nurse Education Today, 34(6), 918-923. https://doi.org/10.1016/j.nedt.2013.12.005

Carson, E. H. (2012). Self-directed learning and academic achievement in secondary online students (Doctoral dissertation). The University of Tennessee. https://scholar.utc.edu/theses/11/

Cazan, A. M., \& Schiopca, B. A. (2014). Self-directed learning, personality traits and academic achievement. Procedia-Social and Behavioral Sciences, 127, 640-644. https://doi.org/10.1016/j.sbspro.2014.03.327

Deyo, Z. M., Huynh, D., Rochester, C., Sturpe, D. A., \& Kiser, K. (2011). Readiness for self-directed learning and academic performance in an abilities laboratory course. American Journal of Pharmaceutical Education, 75(2), 25. https://doi.org/10.5688/ajpe75225

Duckworth, A. L., \& Quinn, P. D. (2009). Development and validation of the short grit scale (GRIT-S). Journal of Personality Assessment, 91(2), 166-174. https://doi.org/10.1080/00223890802634290

Dube, M. B., \& Mlotshwa, P. R. (2018). Factors influencing enrolled nursing students' academic performance at a selected private nursing education institution in $\begin{array}{lll}\text { KwaZulu-Natal. } & \text { Curationis, } & \text { 41(1), }\end{array}$ https://doi.org/10.4102/curationis.v41i1.1850

Fisher, M., King, J., \& Tague, G. (2001). Development of a self-directed learning readiness scale for nursing education. Nurse Education Today, 21(7), 516-525. https://doi.org/10.1054/nedt.2001.0589

Kamali, S., Jafari, E., \& Fathi, A. (2009). Correlation between academic achievement and self-esteem in students of Zanjan Faculty of Nursing and Midwifery 1388. Journal of Medical Education Development, 2(2), 17-24. https://zums.ac.ir//edujournal/browse.php?a_id=17\&sid=1\&slc_lang=en

Mason, H. D. (2018). Grit and academic performance among first-year university students: A brief report. Journal of Psychology in Africa, 28(1), 66-68. https://doi.org/10.1080/14330237.2017.1409478

Murphy, L. S. (2020). relationship between grit and academic success in undergraduate and graduate nursing students (Doctoral Dissertation). Allen College. https://scholarworks.uark.edu/etd/3135/

Oducado, R. M. F., \& Penuela, A. P. (2014). Predictors of academic performance in professional nursing courses in a private nursing school in Kalibo, Aklan, Philippines. Asia Pacific Journal of Education, Arts and Sciences, 1(5), 21-28. http://apjeas.apjmr.com/wp-content/uploads/2014/11/APJEAS-2014-1-079.pdf 
Oducado, R. M. F., Frigillano, P. R. S., Gunce, J. J. T., Jover, P. L. B., Meliton, P. N., \& Pangilinan, K. T. (2017). Guidance needs of nursing students in Iloilo City, Philippines. PEERS Inc. Multidisciplinary Research Journal, 1(2), 35-47. http://hdl.handle.net/10755/17285

Oducado, R. M. F., Cendaña, D. P., \& Belo-Delariarte, R. G. (2019a). Institutional competency assessment and other factors influencing the nurse licensure examination. International Journal of Scientific \& Technology Research, 8(12), 268-270. http://www.ijstr.org/final-print/dec2019/Institutional-CompetencyAssessment-And-Other-Factors-Influencing-The-Nurse-LicensureExamination.pdf

Oducado, R. M. F., Amboy, M. K. Q., Penuela, A. C., \& Belo-Delariarte, R. G. (2019b). Correlation between theoretical classroom instruction and related learning experiences: Evidence from a Philippine nursing university. International Journal of Scientific \& Technology Research, 8(12), 3666-3670. http://hdl.handle.net/10755/19390

Oducado, R. M. F., Sotelo, M., Ramirez, L. M., Habaña, M., \& Belo-Delariarte, R. G. (2020). English language proficiency and its relationship with academic performance and the nurse licensure examination. Nurse Media Journal of Nursing, 10(1), 46-56. https://doi.org/10.14710/nmjn.v10i1.28564

Malaga, X. G., \& Oducado, R. M. F. (2021). Does senior high school strand matter in nursing students' academic self-regulated learning and academic performance?. South East Asia Nursing Research, 3(1), 1-7. https://doi.org/10.26714/seanr.3.1.2021.1-7

Oducado, R. M. F., \& Estoque, H. V. (2021). Online learning in nursing education during the COVID-19 pandemic: Stress, satisfaction, and academic performance. Journal of Nursing Practice, 4(2),143-153. https://doi.org/10.30994/jnp.v4i2.128

Palisoc, A. J. L., Matsumoto, R. R., Ho, J., Perry, P. J., Tang, T. T., \& Ip, E. J. (2017). Relationship between grit with academic performance and attainment of postgraduate training in pharmacy students. American Journal of Pharmaceutical Education, 81(4), 67. https://doi.org/10.5688/ajpe81467

Rosenberg, M. (1965). Rosenberg self-esteem scale (RSE). Acceptance and commitment therapy. Measures Package, 61(52), 18.

Slater, C. E. (2018). Self-directed learning readiness of students in health professional preparation programs: Informing teaching and learning approaches (Doctoral Dissertation). The University of Wollongong. https://ro.uow.edu.au/cgi/viewcontent.cgi?article=1331\&context=theses1 
Smith, E. M. (2017). Noncognitive variables to predict academic success among junior year baccalaureate nursing students (Doctoral Dissertation). Syracuse University. https://surface.syr.edu/etd/683

Soriano, G. P. (2016). Relationship between academic performance and the nursing licensure examination of graduates from a city-subsidized university. Philippine Journal of Nursing, 86(1), 56-62.

Torun, E. D. (2020). Online distance learning in higher education: e-learning readiness as a predictor of academic achievement. Open Praxis, 12(2), 191-208. https://doi.org/10.5944/openpraxis.12.2.1092 